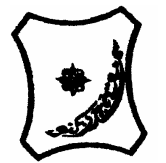

Bayero Journal of Pure and Applied Sciences, 7(2): 145 - 149

Received: August 2014

Accepted: November 2014

ISSN $2006-6996$

\title{
OCCURRENCE OF PATHOGENIC BACTERIA ASSOCIATED WITH CLARIAS GARIEPINUSIN SELECTED FISH FARMS Of KUMBOTSO LOCAL GOVERNEMENT AREA OF KANO STATE, NIGERIA
}

\author{
${ }^{1}$ *Danba, E.P., ${ }^{2}$ Bichi, A.H., ${ }^{3}$ Ishaku, S., ${ }^{2}$ Ahmad, M.K., ${ }^{4}$ Buba, U., ${ }^{1}$ Bingari, M.S., ${ }^{1}$ Barau, \\ B.W. and ${ }^{1}$ Fidelis, U. F. \\ ${ }^{1}$ Department of Biological Science, Taraba State University Jalingo, Taraba State, Nigeria \\ ${ }^{2}$ Department of Biological Science, Bayero University Kano, Nigeria \\ ${ }^{3}$ Department of Agricultural Science, Saadatu Rimi College of Education Kumbotso, Kano State, Nigeria. \\ ${ }^{4}$ Department of Animal Sciences, Taraba State University Jalingo, Taraba State, Nigeria \\ *Correspondence author
}

\begin{abstract}
With the diminishing rate of natural fish resources globally, a reasonable percentage of fish and fish products supply now comes from aquaculture. However, quality production is highly required for sustainable demand and supply. It is in view of the aforementioned that this study was designed to examine the quality status of Clarias gariepinus in relation to pathogenic bacteria in two fish farms in Kumbotso Local Government Area of Kano State, Nigeria. 66 Clarias gariepinus with bodyweight $17 \mathrm{~g}$ - $215 \mathrm{~g}$ were random/y sampled from July to December 2012 followed by the isolation and identification of different pathogenic bacteria from skin and gill. $A$ total of 132 samples comprising skin $\left(1 \mathrm{~cm}^{2}\right)$ and gill (1g) were subjected to microbiological assays in the laboratory following standard procedures. Nutrient Agar, MacConkey Agar, Eoisin Methylene blue, Salmonella Shigella Agar and Blood Agar were used for isolation and maintenance of cultures during the study. Lactose broth, Brilliant Green lactose bile broth (BGLB) was used for the estimation of Escherichia coli Most Probable Number per $1 \mathrm{~cm}^{2}$ of skin and $1 \mathrm{gram}$ of gill (MPN/mI and MPN/g). The highest mean of Aerobic Plate Count (APC) was $1.26 \times 10^{4} \mathrm{cfu} / \mathrm{ml}$ while the highest mean of Escherichia coli MPN/1 $\mathrm{cm}^{2}$ was 8.75 . Bacterial pathogens isolated and percentage occurrences in parenthesis were Escherichia coli (54.27 \%); Stapholococcus aureus (22.48 \%); Pseudomonas aeruginosa (10.85 \%); Salmonella paratyphi (9.30 \%) and Enterobacter aerogenes (3.10\%). There was no significant difference $\left(X^{2}=3.42, P>0.05\right)$ in bacteria isolates from the two fish farms. The result from this study indicated that the fishes were less contaminated with pathogenic bacteria, thus consumers are safe to eat fishes harvested from these farms since all the values are within the recommended limit of $<5 \times 10^{5}$ cfu/g for APC and, 11 for Escherichia coli MPN/ml by International Commission for Microbiological Specification for Food (ICMSF, 2007). Keywords: Fish farm, Clarias gariepinus, Microbiological assays, Pathogenic bacteria.
\end{abstract}

INTRODUCTION

On a global scale, fish and fish products are the most important source of protein and it is estimated that more than $30 \%$ of fish for human consumption comes from aquaculture (Hastein et al., 2006; Yagoub, 2009; Adebayo et al., 2012). Fishery products are important not only from a nutritional point of view, but also as an item of international trade and foreign exchange earner for a number of countries in the world (Yagoub 2009; Adebayo et al., 2012). Fish and shell fish are highly perishable and prone to vast variations in quality due to difference in species, environmental habitants, feeding habits (Yagoub 2009 and Adebayo et al., 2012) In addition, they can also function as carriers of microbial and other health hazards (Yagoub 2009, Adebayo et al., 2012).

Aquatic bacteria that infect fish belong to three groups: the Gram-negative bacteria (most common), Gram - positive bacteria and acid-fast bacteria, which are obtained from food or from the environment. Gram-negative bacteria cause most of the diseases in tropical fish. Several workers have conducted investigations on these bacteria (Ducencic and Candan, 2003; Kar and Ghosh, 2008), some of which are opportunistic pathogens (Schmidt et al., 2000) while others are obligatory pathogens (Tendencic, 2004).

Fish contamination can be linked to raw material, personnel, processing tools such as forklifts through leakage, opening in building and pests. Some pathogens may even become established in the processing plants from niches where they can survive for a long period of time (Adebayo et al., 2012). The tissue of a healthy fish is normally considered sterile until after bacterial invasion that leads to spoilage. According to Adams and Moses (2008), the normal bacterial load of the surface slime of fish can range from $10^{2}-10^{7} \mathrm{cfu} / \mathrm{cm}^{2}$ and the gills and intestines can range up to $10^{3}$ and $10^{7} \mathrm{cfu} / \mathrm{g}$ respectively. The maintenance of quality is of utmost importance in production and trade of fishery product. Most of current quality control techniques are time consuming and cumbersome (Yagoub, 2009, Adebayo et al., 2012). 
Although only a few infectious agents in fish are able to infect humans, some exceptions exist that may result in fatalities (Adebayo et al., 2012). However the greatest risk to human health is due to the consumption of raw or insufficiently processed fish and fish products (Yagoub, 2009; Adebayo et al., 2012; Adedeji et al., 2012). Thus, the aim of the study was to determine the quality status of $C$. gariepinus in Fagam fish farm and Khasu integrated fish farm of Kumbotso local government area of Kano state, Nigeria.

\section{MATERIALS AND METHODS Study Sites}

Fagam fish farm and Khasu integrated fish farm are found in kumbotso Local Government Area, Northwest Nigeria. Fagam fish farm lies between latitude $11^{0} 56^{\prime} 57.79^{\prime \prime} \mathrm{N}$, and longitude $8^{0} 36^{\prime} 57.59^{\prime \prime} \mathrm{E}$, with an elevation of $492 \mathrm{~m}$ while Khasu integrated fish lies and latitude $11^{0} 54^{\prime} 56.65^{\prime \prime} \mathrm{N}$, longitude $8^{0} 25^{\prime} 33.76^{\prime \prime} \mathrm{E}$, with an elevation of $457 \mathrm{~m}$. The area is characterized by two seasons comprising the rainy season (May to September) and the dry season (October to April). Mean annual temperature ranges from $16^{\circ} \mathrm{C}$ to $47^{\circ} \mathrm{C}$ while annual rainfall has a minimum of $700 \mathrm{~mm}$ and a maximum of $1160 \mathrm{~mm}$. The people are predominantly Islamic and the taboo placed meat slaughtered by non-Muslims is adequately taken care of when it comes to fish consumption.

\section{Collection and Processing of Fish Samples}

Live Cultured African Clarias gariepinus were collected from 2 farm ponds. 66 samples of Clarias gariepinus with body weight range between $17 \mathrm{~g}$ and $215 \mathrm{~g}$ were randomly collected from different locations using hand nets. Sampling was done between $7.00-$ 9.00 am on each occasion at periodic interval of seven days for a length of six months. Fish samples were transported in clean polythene bags directly to the Postgraduate Laboratory of Biological Science Department, Bayero University Kano within 2 hours of sampling.

\section{Sampling Preparation}

Bacteria isolated from each specimen were obtained from skin and gill samples by macerating aseptically $1 \mathrm{~cm}^{2}$ of skin and $1 \mathrm{~g}$ of gill separately and swirled in $10 \mathrm{ml}$ distilled water (Emikpe et al., 2011). The stock solution was serially diluted to 10 folds in 9 $\mathrm{ml}$ sterilized peptone water (Merch). A quantity of 0.1 $\mathrm{ml}$ of each dilution was inoculated in Petri dishes of Nutrient Agar and MacConkey agar in duplicates and incubated for $24-48$ hours at $37^{\circ} \mathrm{C}$. All the samples were replicated on different media and the plates were then incubated at $37^{\circ} \mathrm{C}$ for $24-48$ hours. The bacteriological media viz: Nutrient agar, MacConkey agar, Eosin Methylene blue agar, Salmonella-Shigella agar, Mannitol salt agar and Blood agar were prepared according to manufacturer's instructions. The media were sterilized at $121^{\circ} \mathrm{C}$ for 15 minutes in an autoclave (Gallemkamp) and were poured into sterilized disposable dishes (Antec diagnostic). Sterility of the media was confirmed by incubating two uninoculated plates (control) with the inoculated plates. The uninoculated plates were always examined to show no evidence of bacterial growth. Any uninoculated plate that showed evidence of bacterial growth was discarded. The colony count per $1 \mathrm{~cm}^{2}$ and $1 \mathrm{~g}$ of skin and gills was determined using standard method (APHA 1999). The colony count was calculated by dividing the bottom of the Petri dish into four and the sum of bacterial count was multiplied by the dilution factor and divided by the volume of the inoculums. Each distinct colony was further sub cultured on freshly prepared Nutrient agar and MacConkey agar for evaluation of purity and colonial morphology. The isolates were subjected to Gram stain to determine their Gram reaction. Biochemical tests were carried out as described by Cheesbrough (2010) to determine the identity of bacteria isolates with reference to Bergeys Manual of Determinative Bacteriology.

\section{Statistical Analysis}

Descriptive statistics involving the use of tables, percentages and mean values were used to present the data collected while inferential statistics such as Chi-square test was used to determine the variation of isolates between the two farms.

\section{RESULTS}

The results (Table 1 ) of isolates from skin and gills of Clarias gariepinus from 2 fish farms in Kumbotso LGA of Kano state, Nigeria, shows a total of 129 bacterial isolates belonging to 5 genera viz. Escherichia, Staphylococcus, Pseudomonas, Salmonella and Enterobacter as recovered from 66 samples of fish. Escherichia coli (54.27\%) were the most prevalent species identified, followed by Staphylococcus aureus (22.48 \%). Pseudomonas aeruginosa (10.85\%), Salmonella paratyphi (9.30\%), and Enterobacter aerogenes $(3.10 \%)$ were the least from the bottom. The results of the mean aerobic count (Table 2) indicate a higher aerobic count for the skin $\left(2.24 \times 10^{3}\right.$ $\left.\mathrm{cm}^{2}\right)$ and gills $\left(1.96 \times 10^{3} \mathrm{~g}\right)$ in Fagam fish farm than Khasu fish farm whose skin mean aerobic count was $2.00 \times 10^{3} \mathrm{~cm}^{2}$ and $1.26 \times 10^{4} \mathrm{~g}$ for the gills. The means for Means of Escherichia coli MPN/cm ${ }^{2}$ and gram (Table 3) did not indicate any large proximity in both farms (Fagam: Skin $=8.75 \mathrm{MPN} / \mathrm{cm}^{2}$; Gills = 7.57MPN $/ \mathrm{cm}^{2}$ and Khasu: Skin $=7.52 \mathrm{MPN} / \mathrm{cm}^{2}$; Gills $=6.70 \mathrm{MPN} / \mathrm{cm}^{2}$ ). The distribution of pathogens bacteria on skin and gills of Clarias gariepinus was close to somewhat uniform (+) for all the isolates and for the skins and gills except for Enterobacter aerogenes observed to present in gills $(+)$ and not on the skin (-). 
Table 1: Bacteria isolated from skin and gills of Clarias gariepinus fish farm (No of isolates).

\begin{tabular}{lcccc}
\hline Isolate identified & Farm C & Farm D & Total & \%Occurrence \\
\hline Escherichia coli & 30 & 40 & 70 & 54.27 \\
Staphylococcus aureus & 14 & 15 & 29 & 22.48 \\
Pseudomonas aeruginosa & 4 & 10 & 14 & 10.85 \\
Salmonella Paratyphi & 9 & 3 & 12 & 9.30 \\
Enterobacter aerogenes & 4 & - & 4 & 3.10 \\
& 61 & 68 & 129 & 100 \\
\hline
\end{tabular}

$\left(X^{2}=3.42, P>0.05\right)$

Table 2: Means of Aerobic Plate Count of Bacterial isolates from skin and gill of Clarias gariepinus.

\begin{tabular}{lcc}
\hline Farm & Skin $\left(\mathbf{1 c m}^{\mathbf{2}}\right)$ & Gill $\mathbf{( I g )}$ \\
\hline Fagam & $2.24 \times 10^{3}$ & $1.96 \times 10^{3}$ \\
Khasu & $2.00 \times 10^{3}$ & $1.26 \times 10^{4}$ \\
\hline
\end{tabular}

Table 3: Means of Escherichia coli MPN $/ \mathrm{cm}^{2}$ and gram

\begin{tabular}{lll}
\hline Farm & Skin & Gill \\
\hline Fagam & 8.75 & 7.57 \\
Khasu & 7.52 & 6.70 \\
\hline
\end{tabular}

Table 4: Distribution of pathogens bacteria on skin and gill of Clarias gariepinus

\begin{tabular}{lcc}
\hline Isolates & Skin & Gill \\
\hline & & + \\
Escherichia coli & + & + \\
Staphylococcus aureus & + & + \\
Pseudomonas aeruginosa & + & + \\
Salmonella paratyphi & + & + \\
Enterobacter aerogenes & - &
\end{tabular}

\section{DISCUSSION}

Fish in their natural habitat may not be free from bacteria infestation but the rate however is highly dependent on some key environmental and climatic factors as well as the species of fish and bacteria in question. Certain environmental factors tend to encourage the rate infestation while others instead affect bacteria survival and development negatively. The timings of bacteria infestation on fish is also to some extend controlled by seasonal changes with the consequent changes in climatic conditions. Keeping aside the natural habitat and considering the findings from these artificial fish habitat, one may not be out of place to conclude that the presence of these bacteria from skin and gills may be attributed to poor sanitary conditions under which the fishes are cultured in the ponds. This may occur as a result of the low number of pond keepers probably because the farm owners will like to maximize profit by keeping staff trend as low as possible. The idea is usually to make optimum output from the few workers which sometime proof abortive over time. Even when the worker's performance is highly rated, experience may be a major shortcoming because the farm owners also stay away from employing well-trained aquaculture personnel. This may further have its way on the type of feeds being ministered to the fishes. When indiscriminate use of feeds is introduced, the consequence can also be seen on the rate of bacteria infestation. Another potential candidate for prevalence of bacteria in a fishpond could be the irregular draining of ponds: a situation that provides favourable condition for bacteria reproduction and development in their host bodies. The hygienic level of a fishpond begins with the mangers. This is because man is the major cause of problems to his own environment. Therefore, human entry to the fishpond must be well screened to ensure the safety of the inhabitant and where possible restrict the number of people that visit the pond because the findings from this study may probably be as a result of unrestricted entry to the ponds by the public. The use of bare hands when feeding the fishes by the farmers is also likely to have contributed to the observed bacteria pathogens and perhaps the use of dirty equipments such as hand nets or cast nets when catching the fishes. The highest means of Aerobic Plate Count (APC) from $1 \mathrm{~cm}^{2}$ of skin was from Fagam fish farm with $2.24 \mathrm{x}$ $10^{3} \mathrm{cfu} / \mathrm{cm}^{2}$ and $1.26 \times 10^{4} \mathrm{cfu} / \mathrm{g}$ of gills from Khasu integrated fish farm (Table 2), while the highest MPN/ $\mathrm{cm}^{2}$ of Escherichia coli from skin of C. gariepinus was 8.75 and 7.57 for gill, both from Fagam fish farm. (Table 3). Both APC and MPN $/ \mathrm{cm}^{2}$ were within the recommended limit of $<5 \times 10^{5}$ for Aerobic Plate Count and $<11$ for $\mathrm{MPN} / \mathrm{cm}^{2}$ set standard by International Commission for Microbiological Specifications for Food (ICMSF, 2007). This may be an indication that the region is naturally good for fish farming and very little effort can pave the way for high and quality output. 
The distribution of pathogenic bacteria on skin and gill of Clarias gariepinus revealed the occurrence of Escherichia coli, Staphylococcus aureus, Pseudomonas aeruginosa and Salmonella paratyphi while Enterobacter aerogenes were not found in all the skin, but were present in gills (Table 4). Although the bacterial species found in the present study did not cause mortality to the fishes probably because the fishes have strong host defense response yet the species are both opportunistic and pathogenic species which could be involved in causing fish disease (Efuntoye et al., 2012). In addition, these organisms could also be involved in the transmission of diseases to human beings. Fish and fish products have been reported as vehicles of food-borne bacterial infections in humans (Novotyn et al., 2004, Hastein et al., 2006, Efuntoye et al., 2012). The pathogens might have been introduced into the production process by human healthy carriers through handling as reported by (Emikpe et al., 2011). The isolates were isolated from apparently healthy fishes indicating that the organisms do not constitute a serious threat to the fishes in the environment studies. However these organisms are of public health significance. Some of the bacteria species recovered in this study were also identified from healthy Clarias gariepinus in Ago Iwoye, Ibadan, Oyo State Nigeria (Efuntoye et al., 2012). Also, a number of investigators have reported the occurrence of pathogenic bacteria in Clarias gariepinus from fresh water aquaculture environment (Ajayi, 2012; Emikpe et al., 2011; Udeze et al., 2012 and Adedeji et al., 2012). The presence of these bacteria in fish pose a threat to fish consumers as these organisms have been implicated in numbers of diseases.

\section{REFERENCES}

Adams M.R, Moses M. O, (2008): Food Microbiology (Third Edition) The Royal Society of chemistry, Cambridge, UK 2008 179pp.

Adebayo. Tayo B.C; Odu N.N, Anyamele L.M; Igwiloh NJPN; Okonko I.O. (2012): Microbial quality of frozen fish sold in Uyo Metropolis. Nature And science 10(3): $71-77$.

Adedeji, O.B, Okerentugba, P.O, Innocent, D.E, Adiele, H.C and Okonko, I.O. (2012): Benefits, Public Health Hazards and Risks Associated with fish Consumption. New York Science Journal 5 (a):33-61.

Ajayi .A.O (2012): Bacteriological study of catfish, Clarias gariepinus, from fish pond sources in Akungba - Akoko Community Nigeria British Microbiological Research Journal 2(1):1-9.

APHA (American Public Health Association) (1999): Standard Method for Examination of Water and Waste Water, American Water Works Association, Water Environment Federation, 9020B.
Escherichia coli strains have been implicated as causative agent of gastro-enteritis and urinary tract infection (Udeze et al., 2012). Staphylococcus aureus has been associated with different clinical conditions. For instance, it is still one of the most frequently encountered single bacteria species in hospitals and continues to be the common cause of burns and sepsis (Obiazi et al., 2007; Udeze et al., 2012).

\section{CONCLUSION}

Base on the findings from this study, It may not be out of place to conclude that Clarias gariepinus of the two fish farms are of good quality because the aerobic plate count (APC) and $\mathrm{MPN} / \mathrm{cm}^{2}$ and gram were within the recommended limit of $<5 \times 10^{5}$ and $<11$. Therefore, these farms should be encouraged with technologically advanced equipment to boost their production to meet up with the current demand for fish and their products in the region and world market at large. However, the management techniques should be intensified to ensure absolute absence of any kind of bacteria occurrence observed.

\section{Acknowledgement}

We would like to sincerely thank all members of staff of the Department of Biological Sciences, Bayero University, Kano for their guidance and constructive criticism through out this work. The two fish farms granted permission for this research to be carried out and their worker were generally helpful, accept our profound thanks. TETFund through the Taraba State University provided funding and is highly appreciated. Above all, we are grateful to God that this door has closed for the new one to open.

Cheesbrough, M. (2010): District Laboratory Practice in Tropical Countries part 2, Second edition up date. p187-195.

Ducenic, S.K and A. Candan (2003): Isolation of Aeromonas strains from Intestinal of Atlantic Salmon (Salmon salar L., 1758). Turkish Journal of Veterinary and Animal Science,27:1071 - 1075.

Efuntoye, M.O., Olurin, K.B and Jegede, G.C (2012): Bacterial flora from Healthy Clarias gariepinus and their Antimicrobial resistance pattern. Advance Journal of food science and technology 4(3): 121 - 125.

Emikpe, B.O, Adebisi, T. and Adedeji, O.B (2011). Bacteria load on skin and Stomach of Clarias gariepinus and Oreochromis niloticus from Ibadan, Southwest Nigeria. Journal of Applied Science Research 7(7): 1047-1051.

Hastein, T.B, Hjeltnes, J., Lillehaug, U., Skare, M., Berntssen, H. and Lundebye, A.K (2006): Food safety hazards that occur during the production stage: Challenge for fish farming and the fishing industry. Review in Science and Technology 25: 607-625. 
International Commission for Microbiological Specification for Food (ICMSF) (2007): Microorganisms in foods. 2. Sampling for Microbiological analysis: principles and Specific applications $2^{\text {nd }}$ Ed University of Toronto press Buffalo, NY. Available online at: seafood ucdavis. Edu/organize/ICMSF. $\mathrm{Htm}$.

Kar, N and K, Ghosh, (2008): Enzyme producing bacteria in the gastrointestinal tracts of Labe rohita (Hamilton) and Chanma punctata (bloch). Turkish Journal of Fish and Aquatic Science, 8:115-120.

Novotyn. L.,L. Dvorska, A.Lorencova, B. Beran and I Pavlik (2004): Fish: A potential source of bacterial pathogens for human beings. Vet. Med. Czech., 49: 343-358.

Obiazi, H.A. K., Nmorsi, O.P.G., Ekundayo A.O. and Ukwamdu, N.C.D (2007): Prevalence and antibiotic susceptibility pattern of
Staphylococcus aureus from clinical isolates grown at $37^{\circ} \mathrm{C}$ and $44^{\circ} \mathrm{C}$ from Irrua, Nigeria. African journal of Microbiology Research, pp. 057-060.

Schmidt , A.S., M Bruun, S.I. Dalsgard, K.Pedersen and J.Larsen (2000): Occurrence of antimicrobial resistance in fish pathogens and environmental bacteria associated with Danish rainbow trout farms Applied Environment Microbiol, 66: 4915.

Udeze, A.O, Talatu, M, Ezediokpu, M.N., Nmwanze,J.C., Onoh, C. and Ononko, I.O (2012b): The effect Of Klebsiella Pneumoniae on catfish (Clarias gariepinus). Researcher. $4(4): 51-59$.

Yagoub, S.O. (2009): Isolation of enterobactiaceae and Pseudomonas spp from raw fish sold in fish Market in Khartoum state. Journal of Bacteriology Research, 1 (7): 85-88. 